\title{
Incidence, etiology, and course of hypercalcemia-induced AKI in a tertiary care center from northern India
}

\author{
Nucksheeba Aziz Bhat ${ }^{1}$, Farhat Mustafa ${ }^{2}$, Rayees Yousuf Sheikh ${ }^{3^{*}}$ (D) and Imtiyaz Wani ${ }^{4}$
}

\begin{abstract}
Background: Hypercalcemia is known to cause acute kidney injury (AKI). Literature related to hypercalcemic AKI is predominantly in the form of case reports and case series. The purpose of this study is to find the incidence, etiology, and course of hypercalcemia-induced AKI in a non-critical care setting. To our knowledge, this is the first study done to look for the incidence, etiology, and course of hypercalcemia-induced AKI in a non-critical care setting. This is a prospective observational study conducted in the Department of Medicine in a tertiary care center from Jammu and Kashmir, India, from June 2010 to June 2012. Patients admitted with hypercalcemia were assessed for AKI and evaluated and treated for hypercalcemia. Renal function was monitored during hospitalization and at 1 month of discharge. AKI and hypercalcemia were arbitrarily defined as serum creatinine $>1.5 \mathrm{mg} / \mathrm{dl}$ and corrected serum calcium of $\geq 11.5 \mathrm{mg} / \mathrm{dl}$ (as per reference hospital lab), respectively.

Results: Thirty patients are included. Hyperparathyroidism and multiple myeloma accounted for $13(43.3 \%)$ and 10 (33.3\%) cases, respectively. Mean \pm SD corrected serum calcium at diagnosis and after treatment at 1 month was $13.56 \pm 1.86 \mathrm{mg} / \mathrm{dl}$ and $9.49 \pm 1.35 \mathrm{mg} / \mathrm{dl}$, respectively; $p<0.001$. Mean \pm SD serum creatinine at baseline and after treatment of hypercalcemia was $2.87 \pm 1.68 \mathrm{mg} / \mathrm{dl}$ and $1.49 \pm 1.34 \mathrm{mg} / \mathrm{dl}$, respectively; $p<0.001$. Twenty-three $(76.7 \%)$ patients had AKI. AKI recovered after treating hypercalcemia in 25 (83.3 \%) patients. Mean \pm SD days taken for the decrease in serum creatinine to $\leq 1.5 \mathrm{mg} / \mathrm{dl}$ was $8.28 \pm 4.17$ days. Mean \pm SD serum creatinine after treatment of hypercalcemia in hyperparathyroidism group versus non-parathyroid group was $0.97 \pm 0.35 \mathrm{mg} / \mathrm{dl}$ and $1.88 \pm 1.67$ $\mathrm{mg} / \mathrm{dl}$, respectively; $p$ value 0.009 .

Conclusions: Hypercalcemia is commonly associated with AKI. Primary hyperparathyroidism and multiple myeloma account for the majority of the cases. Hypercalcemic AKI with primary hyperparathyroidism is less common and the outcome is better, as compared to non-hyperparathyroidism-related causes. AKI is reversible in most cases.
\end{abstract}

Keywords: Hypercalcemia, AKI, Primary hyperparathyroidism, Multiple myeloma

\section{Background}

Hypercalcemia is a relatively common clinically presenting problem with $90 \%$ of all cases accounted for by primary hyperparathyroidism and malignancy. The differential diagnosis of hypercalcemia consists of parathyroid hormone (PTH)-mediated hypercalcemia and nonPTH-mediated hypercalcemia. Causes of PTH-mediated

\footnotetext{
* Correspondence: Rayees.sheikh@bsh.com.bh; DSRY81@GMAIL.COM ${ }^{3}$ Department of Nephrology, Bahrain Specialist Hospital, Manama, Bahrain Full list of author information is available at the end of the article
}

hypercalcemia include primary hyperparathyroidism, familial hypocalciuric hypercalcemia, and ectopic PTH secretion. Causes of non-PTH-mediated hypercalcemia comprise vitamin D-mediated hypercalcemia (vitamin D intoxication, lymphoma, granulomatous diseases), vitamin A intoxication, hyperthyroidism, drug-induced hypercalcemia (hydrochlorothiazide, theophylline, and lithium), immobilization, milk-alkali syndrome, adrenal insufficiency, and humoral hypercalcemia of malignancy. Hypercalcemia is known to decrease the glomerular

\section{Springer Open}

(- The Author(s). 2021 Open Access This article is licensed under a Creative Commons Attribution 4.0 International License, which permits use, sharing, adaptation, distribution and reproduction in any medium or format, as long as you give appropriate credit to the original author(s) and the source, provide a link to the Creative Commons licence, and indicate if changes were made. The images or other third party material in this article are included in the article's Creative Commons licence, unless indicated otherwise in a credit line to the material. If material is not included in the article's Creative Commons licence and your intended use is not permitted by statutory regulation or exceeds the permitted use, you will need to obtain permission directly from the copyright holder. To view a copy of this licence, visit http://creativecommons.org/licenses/by/4.0/. 
filtration rate and cause acute kidney injury. Literature related to hypercalcemia-induced AKI is predominantly in the form of case reports and case series only. We sought to study the incidence, etiological profile, and course of hypercalcemia-induced AKI in a tertiary care center in northern India. To our knowledge, the present study is the first to describe the incidence, etiological profile, and course of hypercalcemia-induced AKI in a non-critical care setting

\section{Methods}

This is a prospective observational study conducted in the Department of Medicine, in a tertiary care center from Jammu and Kashmir, India. The study was conducted from June 2010 till June 2012. All patients admitted with documented hypercalcemia were assessed for the presence of acute kidney injury and evaluated for the cause of hypercalcemia. AKI and hypercalcemia were arbitrarily defined as serum creatinine $>1.5 \mathrm{mg} / \mathrm{dl}$ (as per the upper limit of the reference hospital lab) and corrected serum calcium of $\geq 11.5 \mathrm{mg} / \mathrm{dl}$ (as per upper limit of the reference hospital lab) respectively. The patients were treated for hypercalcemia and renal function was monitored during the hospital stay and at 1 month of discharge. Serum creatinine was measured using the modified Jaffe kinetic method. Serum iPTH was estimated using solid-phase two-site chemiluminescent enzyme-labeled immunometric assay [1] and 25-OH Vit $\mathrm{D}$ was estimated using solid-phase ELISA [2]. All data are presented as mean \pm SD. Dependent non-parametric data is analyzed by Wilcoxon's matched-pair signedrank test. Mann-Whitney $U$ test is used for nonparametric independent data. The $p$ value of $<0.05$ is taken as significant. Statistical analysis is done using SPSS version 25.

\section{Results}

Thrity patients were included in the study. Men and women accounted for 11 (36.7\%) and 19 (63.3\%) of all the cases, respectively. The mean age at presentation was $50.87 \pm 13.96$ years. The most common presenting symptom was generalized weakness in $66.7 \%$ of patients followed by anorexia and bony pains in $56.7 \%$ and $46.7 \%$, respectively. $23.3 \%$ of patients had pathological fractures. The symptoms were present in multiples. Primary hyperparathyroidism was the most common cause of hypercalcemia, followed by multiple myeloma, accounting for $13(43.3 \%)$ and $10(33.3 \%)$ of cases, respectively (Table 1 ). Mean \pm SD corrected serum calcium at diagnosis and after treatment at 1 month was $13.56 \pm$ $1.86 \mathrm{mg} / \mathrm{dl}$ and $9.49 \pm 1.35 \mathrm{mg} / \mathrm{dl}$, respectively; $p<0.001$. Mean \pm SD serum creatinine at baseline and after treatment of hypercalcemia at 1 month was $2.87 \pm 1.68 \mathrm{mg} / \mathrm{dl}$ and $1.49 \pm 1.34 \mathrm{mg} / \mathrm{dl}$, respectively; $p<0.001$ (Table 2 ).
Table 1 Etiological distribution of hypercalcemia

\begin{tabular}{ll}
\hline Etiology & No of patients (\%) \\
\hline Primary hyperparathyroidism & $13(43.3)$ \\
Multiple myeloma & $10(33.3)$ \\
Vit D toxicity & $5(16.7)$ \\
Pulmonary tuberculosis & $1(3.3)$ \\
Acute leukemia & $1(3.3)$ \\
\hline
\end{tabular}

Twenty-three (76.7\%) patients had AKI, defined as serum creatinine $>1.5 \mathrm{mg} / \mathrm{dl}$. After treatment of hypercalcemia, serum creatinine decreased to $\leq 1.5 \mathrm{mg} / \mathrm{dl}$ in 25 $(83.3 \%)$ patients. Mean \pm SD days taken for the decrease in serum creatinine to $\leq 1.5 \mathrm{mg} / \mathrm{dl}$ was $8.28 \pm 4.17$ days with a median of 7.50 days. AKI was seen in $10 / 10$ (100\%) patients with multiple myeloma and 6/13 (46.2\%) patients with hyperparathyroidism. AKI resolved (decrease in serum creatinine to $\leq 1.5 \mathrm{mg} / \mathrm{dl}$ ) after treatment of hypercalcemia in 5/6 (83.3\%) and 8/10 (80 \%) cases of hyperparathyroidism and multiple myeloma, respectively. After treatment of hypercalcemia $92.3 \%$ of patients with primary hyperparathyroidism had normal renal functions. Serum creatinine decreased with the decrease in serum calcium in all but one patient. Primary hyperparathyroidism was due to parathyroid adenoma in 12 / 13 patients and parathyroid carcinoma in 1/13 patients. Mean \pm SD serum calcium before treatment in the primary hyperparathyroidism group and the nonparathyroid group was $14.39 \pm 2.39 \mathrm{mg} / \mathrm{dl}$ and $12.97 \pm$ $1.15 \mathrm{mg} / \mathrm{dl}$, respectively; $p$ value 0.98 . Mean \pm SD serum calcium after treatment in the primary hyperparathyroidism group and the non- parathyroid group was $8.88 \pm$ $1.32 \mathrm{mg} / \mathrm{dl}$ and $9.98 \pm 1.22 \mathrm{mg} / \mathrm{dl}$, respectively; $p-0.02$. Mean \pm SD serum creatinine before treatment in the primary hyperparathyroidism group and the non- parathyroid group was $2.04 \pm 1.58 \mathrm{mg} / \mathrm{dl}$ and $3.49 \pm 1.51 \mathrm{mg} / \mathrm{dl}$ respectively;(p- 0.009). Mean \pm SD serum creatinine after treatment in the hyperparathyroidism group and the non-parathyroid group was $0.97 \pm 0.35 \mathrm{mg} / \mathrm{dl}$ and $1.88 \pm$ $1.67 \mathrm{mg} / \mathrm{dl}$, respectively; $p 0.009$. Results are summarized in Tables 3 and 4.

\section{Discussion}

Hypercalcemia is associated with acute kidney injury. The reversible decrease in glomerular filtration rate in severe hypercalcemia is thought to be mediated in part by direct renal vasoconstriction. This has been shown in a study comparing renal blood flow and glomerular filtration rates in hypercalcemic and normocalcemic rats [3]. Besides, a defect in urinary concentrating ability, leading to polyuria and polydipsia, results in volume depletion, contributing further to worsening of kidney function. This is thought to be due to the 
Table 2 Distribution of serum calcium and serum creatinine before and after treatment of hypercalcemia

\begin{tabular}{llll}
\hline & Before treatment & After treatment & $\boldsymbol{p}$ value \\
\hline Corrected serum calcium mean $\pm \mathrm{SD}(\mathrm{mg} / \mathrm{dl})$ & $13.59 \pm 1.86$ & $9.49 \pm 1.35$ & $<0.001$ \\
Serum creatinine mean $\pm \mathrm{SD}(\mathrm{mg} / \mathrm{dl})$ & $2.87 \pm 1.68$ & $1.49 \pm 1.34$ & $<0.001$
\end{tabular}

downregulation of aquaporin 2 (AQP2) water channels in the collecting tubules [4] and tubulointerstitial injury caused by calcium deposition in the medulla [5]. In addition, activation of the calcium-sensing receptors present on the basolateral membrane of the thick ascending limb of the loop of Henle reduces calcium and sodium chloride reabsorption in the loop of Henle [6, 7]. AKI caused by hypercalcemia is usually reversible with volume expansion with saline solution and lowering of serum calcium concentration.

Our study enrolled 30 patients. The commonest presenting symptom was a generalized weakness in $66.7 \%$ of patients followed by anorexia and bony pain in $56.7 \%$ and $46.7 \%$, respectively. Polyuria and constipation were present in $33.3 \%$ and $26.67 \%$ of patients, respectively. $23.3 \%$ of patients had pathological fractures. Mental changes in the form of irritability and confusion were seen in $10 \%$ of patients. The symptoms were present in multiples. The symptoms were non-specific, and in almost all, the diagnosis of hypercalcemia was not considered until the blood work revealed hypercalcemia.

Primary hyperparathyroidism is the most common cause of hypercalcemia in the community. It is caused by a single adenoma in about $85 \%$ of cases, with hyperplasia of all four parathyroids in $10 \%$ to $15 \%$ and with carcinoma in less than $2 \%$ [8]. In our study, also, primary hyperparathyroidism was the most common cause of hypercalcemia accounting for $43.3 \%$ of total cases. In $12 / 13$ cases, primary hyperparathyroidism was due to solitary parathyroid adenoma. One of 13 patients had parathyroid carcinoma. In our study, $76.7 \%$ of patients developed AKI. A study done by Cyril Mousseaux et al. [9], showed hypercalcemia-associated AKI in $82.4 \%$ of cases. The median age was 58.5 years as against 53 years in our study. Hematological malignancies accounted for
$44.3 \%$ of all cases as against $36.6 \%$ in our study. The study by Cyril Mousseaux et al. [9] was done in an ICU setting which is possibly the reason for the higher incidence of AKI and higher no of patients with malignancies. A retrospective study done by Miguel Moysés-Neto et al. [10] on 8 patients with hypercalcemia and acute kidney injury, showed improvement in renal functions in all patients after treatment of hypercalcemia. The median time taken for renal recovery was 10.5 days. In our study, all but one patient showed a decrease in serum creatinine following treatment of hypercalcemia. The patient had multiple myeloma as the cause of his hypercalcemia and possibly had paraproteinemia-related kidney disease as the predominant cause of renal dysfunction. The median time taken for renal recovery in our study was 7.50 days. The possible reason for faster recovery in our study was the use of bisphosphonates, in addition to supportive treatment, which was not used in the study done by Miguel Moysés-Neto et al. [10].

In patients with multiple myeloma-associated hypercalcemia, renal failure was seen in $100 \%$ of cases. A study on 56 patients with myeloma and severe renal failure identified hypercalcemia or a nonsteroidal antiinflammatory agent as a potential precipitant of renal failure in $43 \%$ of the cases [11]. Incidence of AKI was less with primary hyperparathyroidism-related hypercalcemia as compared to non-hyperparathyroidism-related hypercalcemia. Similar findings were reported by Lins LE [12]. Furthermore, renal recovery was significantly better with hyperparathyroidism-related hypercalcemic AKI as compared with non- hyperparathyroidism-related hypercalcemic AKI. This is possible because most of the non-hyperparathyroidism-related AKI in our study were secondary to multiple myeloma and Vit-D toxicity. Patients with multiple myeloma have additional

Table 3 Distribution of diagnosis with renal function before and after treatment of hypercalcemia

\begin{tabular}{|c|c|c|c|c|}
\hline Etiology & $\begin{array}{l}\text { Before treatment creatinine } \\
\leq 1.5 \mathrm{mg} / \mathrm{dl}\end{array}$ & $\begin{array}{l}\text { Before treatment creatinine } \\
>1.5 \mathrm{mg} / \mathrm{dl}\end{array}$ & $\begin{array}{l}\text { After treatment creatinine } \\
\leq 1.5 \mathrm{mg} / \mathrm{dl}\end{array}$ & $\begin{array}{l}\text { After treatment creatinine } \\
>1.5 \mathrm{mg} / \mathrm{dl}\end{array}$ \\
\hline $\begin{array}{l}\text { Primary } \\
\text { hyperparathyroidism }\end{array}$ & $7(53.8 \%)$ & $6(46.2)$ & $12(92.3)$ & $1(7.7)$ \\
\hline Multiple myeloma & 0 & $10(100)$ & $8(80)$ & $2(20)$ \\
\hline Vit D toxicity & 0 & $5(100)$ & $3(60)$ & $2(40)$ \\
\hline $\begin{array}{l}\text { Pulmonary } \\
\text { tuberculosis }\end{array}$ & 0 & $1(100)$ & $1(100)$ & 0 \\
\hline Acute leukemia & 0 & $1(100)$ & $1(100)$ & 0 \\
\hline Total & $7 / 30(23.3)$ & 23/30 (76.7) & 25/30 (83.3) & $5 / 30(16.7)$ \\
\hline
\end{tabular}

Figures in parenthesis represent the percentage 
Table 4 Distribution of serum calcium and serum creatinine before and after treatment in the hyperparathyroid and nonhyperparathyroid group

\begin{tabular}{llll}
\hline Parameter & Hyperparathyroidism & Non-hyper-parathyroid related & $P$ value \\
\hline Corrected serum calcium mean \pm SD $(\mathrm{mg} / \mathrm{dl})$ before treatment & $14.39 \pm 2.39$ & $12.97 \pm 1.15$ & 0.98 \\
Corrected serum calcium mean $\pm \mathrm{SD}(\mathrm{mg} / \mathrm{dl})$ after treatment & $8.88 \pm 1.32$ & $9.98 \pm 1.22$ & 0.02 \\
Serum creatinine mean $\pm \mathrm{SD}(\mathrm{mg} / \mathrm{dl})$ before treatment & $2.04 \pm 1.58$ & $3.49 \pm 1.51$ & 0.009 \\
Serum creatinine mean $\pm \mathrm{SD}(\mathrm{mg} / \mathrm{dl})$ after treatment & $0.97 \pm 0.35$ & $1.88 \pm 1.67$ & 0.009 \\
\hline
\end{tabular}

mechanisms in the form of paraproteinemia-related kidney disease, NSAID use, and susceptibility to infections, in addition to hypercalcemia that might give rise to renal dysfunction. Patients with Vit D toxicity invariably have NSAID exposure for chronic pains and aches which increases the risk for hypercalcemiainduced AKI. All patients with primary hyperparathyroidism in our study underwent surgical intervention with rapid and sustained correction of serum calcium which might be the reason for a better outcome of AKI in primary hyperparathyroidism. Treatment for hypercalcemia was directed based on the etiology of hypercalcemia. All patients in our study received $0.9 \%$ saline infusion. The rate of infusion was based on the hydration status of the patient and the 24-h fluid balance, to avoid the risk of volume overload in patients with advanced renal dysfunction. All 13 patients with primary hyperparathyroidism underwent parathyroidectomy. Vitamin D supplements were stopped in all patients with proven vitamin $\mathrm{D}$ toxicity. Three patients with Vit-D toxicity-related hypercalcemia received steroids, and one patient received zoledronic acid (modified dose) in addition to normal saline infusion and steroids. Steroids were given in the form of oral prednisolone at the dose of $1 \mathrm{mg} / \mathrm{kg}$ bodyweight for 4 weeks and were subsequently tapered over the next 4 weeks. All patients receiving steroids were given septran prophylaxis. Four of 10 patients with multiple myeloma received chemotherapy. Five of 10 received modified dose zoledronic acid infusion. Zoledronic acid was given at the dose of $2 \mathrm{mg}$ diluted in $100 \mathrm{cc}$ of normal saline slowly iv over $2 \mathrm{~h}$. Patient with pulmonary tuberculosis received normal saline infusion and was started on modified dose antitubercular treatment. A patient with acute leukemia was initiated on chemotherapy.

There are certain limitations to this study. First, the number of patients included in the study is small. Second, we do not have any follow-up of patients beyond 1 month. Third, we don't have kidney biopsy data to determine the cause of persistent renal dysfunction in 5 patients. A bigger study would be required to confirm the findings of our study.

\section{Conclusions}

Hypercalcemia is commonly associated with AKI. Primary hyperparathyroidism and multiple myeloma account for the majority of cases. Hypercalcemic AKI with primary hyperparathyroidism is less common and the outcome is better, as compared to nonhyperparathyroidism-related causes. AKI is reversible in most cases.

\section{Abbreviations}

AKI: Acute kidney injury

\section{Supplementary Information}

The online version contains supplementary material available at https://doi. org/10.1186/s43162-021-00067-8.

Additional file 1.

Acknowledgements

Dr. Abdul Rashid Reshi, Professor of Nephrology for his guidance during the conduct of the study.

Authors' contributions

NA, FM, RS, and IW contributed to the design and development of the study. NA, FM, and RS contributed to data collection. NA, FM, RS, and IW contributed data analysis and interpretation. NA, FM, RS participated in the writing of the manuscript. RS and IW participated in the critical review. NA, FM, RS, and IW provided approval for the final manuscript.

\section{Funding}

The study is not funded.

Availability of data and materials

The data and material would be made available on request.

\section{Declarations}

Ethics approval and consent to participate

The study is approved by SKIMS institutional ethics committee on $6^{\text {th }}$ May 2010. Since this is an observational study wherein the study participants received standard treatment protocol, the consent to participate was waived off by the SKIMS institutional ethics committee.

Consent for publication

Not applicable

Competing interests

There are no conflicts of interest.

Author details

${ }^{1}$ Government Medical College, Department of Pediatrics, GB Pant

Cantonment Hospital, Srinagar, India. ${ }^{2}$ Government Medical College, 
Department of Medicine, SMHS Hospital, Srinagar, India. ${ }^{3}$ Department of Nephrology, Bahrain Specialist Hospital, Manama, Bahrain. ${ }^{4}$ Sheri-Kashmir Institute of Medical Sciences, Srinagar, India.

Received: 13 March 2021 Accepted: 18 April 2021

Published online: 02 November 2021

\section{References}

1. Girish P, Lala M, Chadha M, Shah NF, Chauhan PH (2012) Study of primary hyperparathyroidism. Indian J Endocrinol Metab 16(Suppl 2):S418-SS20. https://doi.org/10.4103/2230-8210.104114

2. He CS, Gleeson M, Fraser WD (2013) Measurement of Circulating 25Hydroxy Vitamin D Using Three Commercial Enzyme-Linked Immunosorbent assay Kits with Comparison to Liquid chromatography. ISRN NutrTandem Mass Spectrometry Meth 723139:1-6. https://doi.org/10. 5402/2013/723139

3. Levi M, Ellis MA, Berl T (1983) Control of renal hemodynamics and glomerular filtration rate in chronic hypercalcemia. Role of prostaglandins, renin-angiotensin system, and calcium. J Clin Invest 71(6):1624-1632. https://doi.org/10.1172/JCl110918

4. Earm JH, Christensen BM, Frokiaer J et al (1998) Decreased aquaporin-2 expression and apical plasma membrane delivery in kidney collecting ducts of polyuric hypercalcemic rats. J Am Soc Nephrol 9(12):2181-2193. https:// doi.org/10.1681/ASN.V9122181

5. Rosen S, Greenfeld Z, Bernheim J, Rathaus M, Podjarny E, Brezis M (1990) Hypercalcemic nephropathy: chronic disease with predominant medullary inner stripe injury. Kidney Int 37(4):1067-1075. https://doi.org/10.1038/ki.1 990.87

6. Hebert SC (1996) Extracellular calcium sensing receptor: implications for calcium and magnesium handling in the kidney. Kidney Int 50(6):21292139. https://doi.org/10.1038/ki.1996.539

7. Peterson LN, McKay AJ, Borzecki JS (1993) Endogenous prostaglandin E2 mediates inhibition of rat thick ascending limb Cl reabsorption in chronic hypercalcemia. J Clin Invest 91(6):2399-2307. https://doi.org/10.1172/JCl1164 73

8. Martin TJ, Grill V (1995) Hypercalcaemia. Clin Endocrinol 42(5):535-538. https://doi.org/10.1111/j.1365-2265.1995.tb02674.x

9. Mousseaux C, Dupont A, Rafat C, Ekpe K, Ghrenassia E, Kerhuel L, Ardisson F, Mariotte E, Lemiale V, Schlemmer B, Azoulay E, Zafrani L (2019) Epidemiology, clinical features, and management of severe hypercalcemia in critically ill patients. Ann Intensive Care 9(1):133. https://doi.org/10.1186/ s13613-019-0606-8

10. Moysés-Neto M, Guimarães FM, Ayoub FH, Vieira-Neto OM, Costa JAC, Dantas M (2006) Acute Renal Failure and Hypercalcemia. Ren Fail 28(2):153159. https://doi.org/10.1080/08860220500531005

11. Irish AB, Winearls CG, Littlewood T (1997) Presentation and survival of patients with severe renal failure and myeloma. QJM. 90(12):773-780. https://doi.org/10.1093/aimed/90.12.773

12. Lins LE (1978) Reversible renal failure caused by hypercalcemia. A retrospective study. Acta Med Scand 203(4):309-314. https://doi.org/1 0.1111/j.0954-6820.1978.tb14879.x

\section{Publisher's Note}

Springer Nature remains neutral with regard to jurisdictional claims in published maps and institutional affiliations.

\section{Submit your manuscript to a SpringerOpen ${ }^{\circ}$ journal and benefit from:}

- Convenient online submission

- Rigorous peer review

- Open access: articles freely available online

- High visibility within the field

- Retaining the copyright to your article

Submit your next manuscript at $\boldsymbol{\nabla}$ springeropen.com 